\title{
HYDROECOLOGICAL MONITORING OVER THE IMPACT OF THE "TERNIVSKA" MINE ON THE BIOCENOSES OF THE SAKSAGAN RIVER (KRIVYI RIH, UKRAINE)
}

\author{
Marenkov O. M., Nesterenko O. S.
}

\section{INTRODUCTION}

Small rivers of Ukraine that pass through the mining regions often fall under an anthropogenic impact, which affects the quantitative and qualitative indicators of their biological diversity. Today, there is a demand for environmental monitoring over the quality of the water environment being the habitat of hydrobionts, which is influenced by mining enterprises.

One of the common examples of such technogenic ecosystems is the Saksagan River, which is located in the center of the industrial agglomeration of Krivyi Rih. The natural regime of the river has been changed by the regulating influence of dams, the discharge of wastewater, including industrial effluents, water intake in technical needs for industrial water supply, and the regulation of the riverbed for industrial needs.

The purpose of the research is to study the current population indicators of the ichthyofauna and other components of the biocenosis of the Saksagan River under the conditions of planned operation of the "Ternivska" mine.

The planned operation of PJSC "KRYVBASZALIZRUDKOM" lies in continuing the production of high-grade iron ore at the field of the "Ternivska" mine according to a Special permit for the use of subsoil dated 12.10.2001, № 2556, Order of the State Service of Geology and Subsoil of Ukraine dated 31.10.2018, № 410-extension of validity; dated 31.10.2018, № 412-amendments.

The impact of the planned operation on the water environment of the Saksagan River is primarily conditional upon the formed surface run-off of the water from the industrial site of "Ternivska" mine, which after purification on a local effluent treatment plant is discharged to the Saksagan River.

The "Ternivska" mine of PJSC "Krivbasszhelezrudkom" has one release (№ 1) of return water (rain and meltwater from the territory of the industrial site) into the Saksagan River. The discharge of treated wastewater (rain and meltwater from the industrial site) into the Saksagan river is carried out based on a special water use permit № 363/DP/49d-18 dated 27.06.2018.

The work on monitoring the impact of the planned operation of the "Ternivska" mine on the populations of ichthyofauna and other components of the Saksagan river biocenosis was carried out by employees of the 
Hydrobiology, ichthyology, and radiobiology research laboratory of the Research Institute of biology of Oles Honchar DNU in 2019-2020, taking into account the current state of the environmental components, direct and indirect cumulative impact of existing objects.

\section{Materials and methods of the research}

Hydrochemical research. The research on the hydrochemical regime has been carried out according to generally accepted methods ${ }^{1}$. Hydrobiological samples were collected in June 2020 at 6 sections (stations) of the Saksagan River, namely:

- 500 meters above the discharge of wastewaters (rain and meltwater) of the "Ternivska" mine (point № 1);

- in the № 1, 2 places of discharge of wastewater (rain and meltwater) of the "Ternivska" mine (point № 2);

- 500 meters below the discharge of wastewater (rain and meltwater) from the "Ternivska" mine (point № 3).

The following indicators are determined for water: the hydrogen index $(\mathrm{pH})$, dissolved gases, biogenic elements, water hardness, temperature, electrical conductivity, and total mineralization (salinity). Indicators of the chemical composition of water are compared with the regulatory criteria of water quality according to hygienic and environmental criteria (DSTU 4808: 2007). The indicators were determined with the EZODO AZ-86031 hydrochemical device (Oximeter/pH meter/conductometer/salimeter) and a set of TESTLAB (JBL, Germany) rapid tests for quick determination of water quality.

Hydrobiological research methods. Phyto-, zooplankton, and zoobenthos samples were collected and processed using traditional hydrobiological methods ${ }^{2}$.

Phytoplankton. Algological water samples were collected using Molchanov bathometer and Apstein grid. The species were identified according to conventional methods ${ }^{3}$. The biomass was calculated through the volume of cells, taking the specific weight of algae equal to one $e^{4}$. The dominance was estimated through biomass. The species is regarded as dominant if its total biomass is at least $80 \%$ of the total phytoplankton biomass.

Zooplankton. Zooplankton was sampled using a common method of straining 50 or $100 \mathrm{dm}^{3}$ of water through the Apstein plankton grid (gauze № 71), followed by fixing with $4 \%$ formaldehyde. The qualitative

\footnotetext{
${ }^{1}$ Методи гідроекологічних досліджень поверхневих вод / під ред. В.Д. Романенко. Київ, 2006. $628 \mathrm{c}$.

2 Методические рекомендации по сбору и обработке материалов при гидробиологических исследованиях. Зоопланктон и его продукция. Ленинград : ЗИН, 1984. 35 с.

3 Гринь В.Г. Об'ємно-вагова характеристика провідних видів фітопланктону Нижнього Дніпра. Питання екології і цеенологї̈ водних організмів Дніпра. АН УССР. Київ, 1963. С. 35-40.

${ }^{4}$ Щербак В.І. Методи досліджень фітопланктону. Методичні основи гідробіологічних досліджень водних екосистем. Київ, 2002. С. 41-48.
} 
composition and quantitative development of zooplankton was determined. Quantitative processing of samples was performed by counting in the Bogorov chamber, taking into account the number of organisms of different sizes and age groups. The biomass was calculated using the formula of mass dependence on body length:

$$
\mathrm{w}=\mathrm{ql}^{3} \text {, }
$$

where $l$ is the body length, $w$ is the mass, and $q$ is the proportionality factor.

Zoobenthos. The zoobenthos was sampled with Ekman-Birge bottom sampler (with a capture area of $0.004 \mathrm{~m}^{2}$ ) and hydrobiological scrapers nets (diameter of the scraper net hoop is $20-25 \mathrm{~cm}$ ), which are more convenient to take samples in shallow water areas of the reservoir at a depth of $1.0-1.5 \mathrm{~m}$. At each station, two samples were selected using a stem bottom sampler and one sample using a hydrobiological scraper net according to the standard method $^{5}$.

The bottom inhabitants were fixed in $4 \%$ formalin solution. The soil was washed through a grid of close-meshed mill gauze. Samples were weighted on torsion scales by groups. The species composition was determined using "MICROmed" XS-2610 and "Carl Zeiss Jenamed 2" microscopes. The average abundance and biomass values for macrozoobenthos groups were calculated as the arithmetic mean where the specified species occurred during the study period. The occurrence is determined for each species (in percent), which is expressed as the ratio of samples where the species was detected to the total number of samples collected during the entire research period at a particular station. This indicator is calculated using the formula:

$$
\mathrm{P}=(\mathrm{m} / \mathrm{n}) 100 \%,
$$

where $m$ is the number of samples (stations) where this species was found, and $\mathrm{n}$ is the total number of samples (stations).

Ichthyofauna. Fish were caught in June in shallow waters. The fishing gear was a $10 \mathrm{~m}$ long cloth drag seine, fish traps, and $1 \mathrm{x} 1 \mathrm{~m}$ lift net. The total catch of juvenile fish was sorted by species, their number was calculated; their length was measured with an accuracy of $1 \mathrm{~mm}$ and the mass of individuals with an accuracy of $0.01 \mathrm{~g}^{6}$. The relative number is calculated as the number of individuals per $100 \mathrm{~m}^{2}$ of the area of the catch ${ }^{7,8}$. The species were determined according to A.F. Koblytska ${ }^{9}$.

\footnotetext{
5 Жадин В.И. Методика изучения донной фауны водоемов и экология донных беспозвоночных). Жизнь пресных вод СССР. Москва : Наука, 1956. Т. 4. Ч. 1. С. 279-382.

${ }^{6}$ Озінковська С.П., Єрко В.М., Коханова Г.Д., Тарасова О.М., Полторацька В.І. Методика збору і обробки іхтіологічних і гідробіологічних матеріалів 3 метою визначення лімітів промислового вилучення риб з великих водосховищ і лиманів України. Київ : ІРГ УААН, 1998. 47 с.

7 Исследования размножения и развития рыб : методическое пособие / под ред. Б.В. Кошелева, М.В. Гулидова. Москва : Наука, 1981. 224 с.
} 
Methods of biotesting. Biotesting of water samples was carried out using experimental test objects Daphnia magna according to KND 211.1.4.054-97. Daphnia juveniles of age less than 24 hours were used to test the toxicity of the samples.

On the day of testing, adult females were separated from the juveniles. The juveniles were selected using a pipette with a wide spout. During the transfer, the juveniles did not contact with the air; the maximum volume during the selection of juveniles was $2 \mathrm{ml}$. The method is based on determining a difference between the number of dead daphnias in the control and the test samples.

The studied water samples were poured into a $100 \mathrm{~cm}^{3}$ glass container. The same volume of distilled water was added to the control sample (control). 10 daphnias at the age of up to 24 hours were placed in each of the experimental and control vessels. During biotesting daphnias were not fed; the number of living test objects was visually determined at the end of the experiment.

The results were recorded after 96 hours. Daphnias were considered to be alive if they moved freely in the water column and reacted to light. The rest of the daphnias were considered dead. The number of alive daphnias in the control and experiment groups gave arithmetic averages, which were used to calculate the number of dead daphnias in the experiment in relation to the control using the formula (3):

$$
\mathrm{A}=[(\mathrm{Xk}-\mathrm{Xd}) / \mathrm{Xk}] \cdot 100 \%,
$$

where $\mathrm{A}$ is the number of dead daphnias in the experiment relative to the control, \%; Xk is the arithmetic mean of the number of alive daphnias in the control, individuals; $\mathrm{Xd}$ is the arithmetic mean of the number of alive daphnias in the experiment, individuals.

If more than $50 \%$ of the test organisms die within 96 hours, it is considered that the test sample has an acute toxic effect on daphnias; if this amount is less than $50 \%$, it indicates the absence of an acute toxic effect of the experimental sample on the test organisms. The lower the average value of the lethal time, the more toxic the test water is. The results of biotesting are considered reliable if the death of daphnias in the control does not exceed $10 \%$.

The obtained results were subject to the variation statistics processing. The difference significance between the experimental data obtained and the control data were evaluated using the Student's t-test. The null hypothesis was rejected at $\mathrm{p} \leq 0.05$. All calculations were performed using the Statistica 6.0 software package.

\footnotetext{
${ }^{8}$ Кузнецов В.А. Количественный учет молоди рыб в водохранилищах и озерах (методические подходы и возможности). Типовые методики исследования продуктивности видов рыб в пределах их ареалов. Вильнюс, 1985. С. 26-35.

${ }^{9}$ Коблицкая А.Ф. Определитель молоди пресноводных рыб. Москва : Легк. и пищ. пром-сть, 1981. $208 \mathrm{c}$.
} 


\section{General physical and geographical characteristics of the research area}

Saksagan is a river in Ukraine that flows within the southern slopes of the Dnieper Upland, Verkhnodniprovsk, Piatykhatky, Sofiyivka, and Kryvyi Rih districts of the Dnipropetrovsk region.

The river has its origin to the North-East of the village of Malooleksandrivka, which is near the town of Verkhivtseve. It flows mainly to the South-West (in some places to the West). It flows into the Inhulets River in the South-Western part of Kriviy Rih city; it belongs to the category of small rivers.

The basin of the Saksagan River has an elongated shape from the northeast to the southwest. The length of the basin is $90 \mathrm{~km}$, the average width is $22 \mathrm{~km}$, and the largest is $43 \mathrm{~km}$. The relief of the basin is hilly; the depth of erosion dissection of the relief by rivers and draws is $50-80 \mathrm{~m}$.

The Saksagan River is the II order tributary of the Dnipro River. The sources of the river are located at an altitude of $140 \mathrm{~m}$, and the mouth is $31 \mathrm{~m}$. The river is $140 \mathrm{~km}$ long. The river has an extensive hydrographic network and consists of 10 rivers more than $10 \mathrm{~km}$ long each, 29 rivers less than $10 \mathrm{~km}$ that have a relatively constant flow, and about 100 insignificant, usually dry draws that have a surface drain during spring snowmelt and summer showers.

The main tributaries are the Losovatka and Demuryna Rivers. The largest tributary of the Saksagan River, the Lozovatka River, has channel legislation of $28.8 \mathrm{~km}$, a basin area of $436 \mathrm{~km}^{2}$ and 5 own tributaries.

The river valley is right-sided with a clear asymmetry of slopes. The slopes, especially on the right, are divided by numerous ravines and draws. The width of the valley varies from $0.6 \mathrm{~km}$ at the outlet to $4.5 \mathrm{~km}$ below Serhiyivka village, most often reaching $1.5-2.5 \mathrm{~km}$. The slopes are mostly outbowed, 30-40 m high, moderately steep. Behind Varvarivka village and below the Bozhedarivka village slopes are weakly desiccated, becoming strongly desiccated farther. They are composed of clay and dusty-heavy loam soils with a lot of crystalline rocks outcrops; limestone is found only in Sayivka village. The depth of the erosion shut-in of the valley is $40-118 \mathrm{~m}$. The steepness of the right-bank slopes is $3-10^{\circ}$; it is $1-6^{\circ}$ on the left-bank slopes.

The floodplain of the Saksagan River is narrow, mostly two-sided. In some areas where the Saksagan River has laid its course in the rocks, there is no floodplain. The terrain of the floodplain is flat. The width of the floodplain in the upper reaches of the river is $30-70 \mathrm{~m}$, in the middle reaches it widens to 150-200 m, sometimes to $400 \mathrm{~m}$. In the lower reaches, below the Makortivsky reservoir dam, the width of the floodplain narrows to $30-50 \mathrm{~m}$; it is just a silted channel, without a floodplain. Below, within Kryvyi Rih, the floodplain widens in some places up to $1.5-2 \mathrm{~km}$, in other places narrows to $70-100 \mathrm{~m}$.

Flow regulation of the Saksagan River basin with ponds and reservoirs is excessive. The basin has 203 ponds with a total water mirror area of $10.2 \mathrm{~km}^{2}$ 
and a volume of 34.2 million $\mathrm{m}^{3}$. Moreover, there are 6 reservoirs with a water mirror area of $21.7 \mathrm{~km}^{2}$ and a volume of 75.8 million $\mathrm{m}^{3}$. For example, Makortivske and Kresivske reservoirs are medium-sized reservoirs (the volume of reservoirs is more than 10 million $\mathrm{m}^{3}$ ) and have the largest share of regulation in the basin: their total volume is 68.1 million $\mathrm{m}^{3}$ ( $62 \%$ of the total volume of regulation).

The supply of the Saksagan River is formed from the runoff of surface waters from rains and snowmelt, spring supply. Within the city of Kryvyi Rih industrial effluents are discharged into the riverbed.

The riverbed of the Saksagan is unbranched; up to the village of Varvarivka it is slightly tortuous and below this village it is tortuous. In the upper reaches, the riverbed is straightened while in the middle and lower reaches it is moderately torturous. The average tortuosity coefficient is 1.27.

In areas where the river bends around the crystalline rocks, a large number of bends were formed, the largest of which are Kresivsky, Oktyabrsky, Shmakivsky and Mudrenyi.

In the lower part within the city of Kryvyi Rih, the width of the Saksagan riverbed is $40-60 \mathrm{~m}$, in some places, it is heavily silted up and swampy. There are areas overgrown with reeds by $80 \%$, and sometimes-by $100 \%$.

The riverbed in many places of the upper and middle reaches is weakly embedded in the bottom of the valley. For a considerable length, it is dry, the stretches are punctuated with shallow areas and it is overgrown with aquatic vegetation. The prevailing width of the river on the stretches is $20-40 \mathrm{~m}$, the depth is $2-3 \mathrm{~m}$; on the ripples, the riverbed narrows to $5-10 \mathrm{~m}$, and the depth decreases to $0.5-1 \mathrm{~m}$. The river has the greatest width of $600 \mathrm{~m}$ in the upper reach of the Kresivsky reservoir near the village of Sokolovka.

In the city of Krivyi Rih, some sections of the riverbed have been cleared. The riverbed consists of such soils as loam silt, pebbles, boulders, sometimes rocks as limestone, granites.

The river slope is $0.8 \mathrm{~m} / \mathrm{km}$. The flow speed is insignificant, the maximum is $0.13-0.4 \mathrm{~m} / \mathrm{s}$ in the lower reaches of the river.

According to the data of previous years, the main pollutants coming from permanent water discharges in the Saksagan River are the following: chlorides $-624 \mathrm{mg} / 1$, sulfates $-1015 \mathrm{mg} / \mathrm{l}$, ammonium nitrogen $-0.56 \mathrm{mg} / \mathrm{l}$, nitrates $-1.4 \mathrm{mg} / \mathrm{l}$, nitrites $-0.07 \mathrm{mg} / 1$, petroleum products $-0.3 \mathrm{mg} / 1$, iron $14 \mathrm{mg} / \mathrm{l}$, phenols $-0.001 \mathrm{mg} / \mathrm{l}$, phosphates $-0.15 \mathrm{mg} / \mathrm{l}$, suspended solids $14 \mathrm{mg} / \mathrm{l}$. The total salinity of the Saksagan River water is $2850 \mathrm{mg} / \mathrm{l}$.

The natural regime of the river is changing under anthropogenic influence. This includes the impact of dams, water discharge, and water withdrawal for technical needs. The largest expenditure of the Saksagan River water reaches $240 \mathrm{~m}^{3} / \mathrm{s}$. 


\section{The results of the research}

Hydrochemical analysis. For the rapid assessment of water quality as a habitat for hydrobionts, a field assessment of hydrochemical indicators was carried out using the TESTLAB hydrochemical kit (JBL, Germany).

This approach makes it possible to determine the water quality during sampling and quickly determine the ecotoxicological state of the water environment. The following parameters were determined in the study of water: the content of ammonium $\left(\mathrm{NH}_{4}{ }^{+}\right)$, nitrites $\left(\mathrm{NO}_{2}{ }^{-}\right)$, nitrates $\left(\mathrm{NO}_{3}{ }^{-}\right)$, iron $\left(\mathrm{Fe}^{2+}\right)$, phosphates $\left(\mathrm{PO}_{4}{ }^{3-}\right)$. The results of the rapid assessment are shown in table 1 .

According to the study results, the water at all the studied sampling points corresponds to the physical and chemical parameters of DSTU 4808: 2007.

Table 1

Results of rapid assessment of the quality of the water environment of the Saksagan River in the area of issue № 1 of the "Ternivska" mine

\begin{tabular}{|c|c|c|c|}
\hline \multirow{2}{*}{ Indicator } & \multicolumn{3}{|c|}{ Date of measurement 09.06.2020 } \\
\cline { 2 - 4 } & Point № 1 & Point № 2 & Point № 3 \\
\hline $\mathrm{NH}_{4}^{+}, \mathrm{mg} / \mathrm{dm}^{3}$ & $<0,05$ & $<0,05$ & $<0,05$ \\
\hline $\mathrm{NO}_{2}^{-}, \mathrm{mg} / \mathrm{dm}^{3}$ & $<0,01$ & $<0,01$ & $<0,01$ \\
\hline $\mathrm{NO}_{3}{ }^{-}, \mathrm{mg} / \mathrm{dm}^{3}$ & $<0,5$ & $<0,5$ & $<0,5$ \\
\hline $\mathrm{Fe}^{2+}, \mathrm{mg} / \mathrm{dm}^{3}$ & $<0,02$ & $<0,02$ & $<0,02$ \\
\hline $\mathrm{PO}_{4}^{3-}, \mathrm{mg} / \mathrm{dm}^{3}$ & 0.1 & 0.5 & $<0,02$ \\
\hline
\end{tabular}

Note: point № 1: $500 \mathrm{~m}$ above the discharge of return water (rain and meltwater); point № 2: the place of return water discharge (rain and meltwater); point № 3: $500 \mathrm{~m}$ below the discharge of return water (rain and meltwater)

The results of hydrochemical analysis have revealed that the content of ammonium nitrogen $\left(\mathrm{NH}_{4}{ }^{+}\right)$at all research points is $0.05 \mathrm{mg} \mathrm{N} / \mathrm{dm}^{3}$, which does not exceed the requirements for water quality and characterizes it within the 1st quality class. The content of nitrites in all research points does not exceed the maximum permissible concentrations and corresponds to the 2 nd class of water quality. The content of nitrates $\left(\mathrm{NO}_{3}{ }^{-}\right)$at all research sites also does not exceed the maximum permissible concentration of $<0.5 \mathrm{mg} / \mathrm{dm}^{3}$, which corresponds to the 3rd class of water quality. The content of iron $\left(\mathrm{Fe}^{2+}\right)$ in the water at the research points was satisfactory and characterizes it within the 1st quality class.

Regarding the content of phosphates, their content is at the level of $<0.02 \mathrm{mg} / \mathrm{dm}^{3}-<0.5 \mathrm{mg} / \mathrm{dm}^{3}$, which corresponds to the standards of DSTU 4808: 2007.

Analyzing the data obtained with previous studies, the content of ammonium nitrogen $\left(\mathrm{NH}_{4}{ }^{+}\right)$at the experimental points has decreased by half. The content of nitrites $\left(\mathrm{NO}_{2}{ }^{-}\right)$and iron $\left(\mathrm{Fe}^{2+}\right)$ in water also tends to gradually decrease. As for the content of phosphates $\left(\mathrm{PO}_{4}{ }^{3-}\right)$, their content has not changed significantly 
except at the sampling point above the discharge of wastewater (rain and meltwater), where the indicator has increased. The content of phosphorus compounds is subject to seasonal fluctuations since it depends on the ratio of the photosynthesis intensity and biochemical oxidation of organic substances.

Under the technical specification, the following parameters have been determined using the EZODO AZ-86031 hydrochemical device (Oximeter/ $\mathrm{pH}$ meter/conductometer/salimeter): temperature $\left(\mathrm{t}^{\circ} \mathrm{C}\right)$, hydrogen index $(\mathrm{pH})$, oxygen content, salinity and conductivity of the water.

The average water temperature at the sampling points is at the level of $+26-27^{\circ} \mathrm{C}$. The $\mathrm{pH}$ value of hydrogen varies within acceptable limits from 8.1 to 8.3. There are significant seasonal changes in the $\mathrm{pH}$ value, mainly due to the state of carbonate balance. It is known that photosynthesis processes that are more intensive in the summer lead to an increase in $\mathrm{pH}$. The amount of mineralization in various parts of the experimental reservoir varied from $1750,0 \mathrm{mg} / \mathrm{dm}^{3}$ at the point of discharge of return water (rain and meltwater) to $2230.0 \mathrm{mg} / \mathrm{dm}^{3}$ at the point below the discharge of return water (rain and meltwater).

The lowest water conductivity index was at points below the discharge of return water (rain and meltwater) and reached $766 \mu \mathrm{S}$, and the largest one was noted at a point above the discharge of return water (rain and meltwater) and amounted to $798 \mu \mathrm{S}$ (table 2).

Table 2

Hydrochemical indicators of the water of the Saksagan River, 09.06.2020

\begin{tabular}{|c|c|c|c|c|c|c|}
\hline Sampling point & $\mathrm{pH}$ & $t^{0} \mathrm{C}$ & $\begin{array}{l}\text { Oxygen } \\
\text { content, } \\
\mathrm{mg} / \mathrm{dm}^{3}\end{array}$ & $\begin{array}{c}\text { Oxygen } \\
\text { content, } \\
\%\end{array}$ & $\begin{array}{l}\text { Minerali- } \\
\text { zation, } \\
\mathrm{mg} / \mathrm{dm}^{3}\end{array}$ & $\begin{array}{c}\text { Conduc- } \\
\text { tivity, } \\
\mu \mathrm{S}\end{array}$ \\
\hline \multicolumn{7}{|c|}{ "Ternivska" mine } \\
\hline $\begin{array}{l}500 \mathrm{~m} \text { above the discharge of } \\
\text { return water (rain and meltwater) }\end{array}$ & 8.2 & 26.1 & 8 & 57.1 & 1750.0 & 798.0 \\
\hline $\begin{array}{l}\text { Place of discharge of wastewater } \\
\text { (rain and meltwater) }\end{array}$ & 8.1 & 26.6 & 6 & 42.9 & 1900.0 & 775.0 \\
\hline $\begin{array}{l}500 \mathrm{~m} \text { below the discharge of } \\
\text { return water (rain and meltwater) }\end{array}$ & 8.3 & 27.1 & 6.2 & 44.3 & 2230.0 & 766.0 \\
\hline
\end{tabular}

It has been found that water salinity decreased by $41 \%$, and water conductivity increased slightly compared to the data from previous studies. Indicators of water salinity and the content of major ions in water are subject to transformation under the influence of anthropogenic load, as well as due to the natural factors such as fluctuations in river water content, which is associated with climate changes. The conductivity of water depends mainly on the concentration of dissolved mineral salts and temperature.

The highest oxygen content in water was recorded in the place above the discharge of return water (rain and meltwater) and amounted to $57.1 \%$, and 
the lowest indicator was in the place of discharge of return water (rain and meltwater), which was $42.9 \%$. The content of dissolved oxygen in water fluctuates daily and seasonally.

Determination of toxicity of the water from Saksagan River in the area of "Ternivska" mine discharge on Daphnia magna Straus crustaceans. When conducting biotesting for acute toxic effects of water, it has been found that in the control samples all daphnias were alive, that is, the results are reliable. The mortality rate in the experimental samples did not exceed $50 \%$. None of the samples have shown acute toxic effects of water (table 3 ). The highest percentage of dead daphnias was in water samples from the point above and below the discharge of return water (rain and meltwater), which was $20 \%$, but the data obtained do not exceed the standard indicators. At the sampling point in the discharge of return water (rain and meltwater), the percentage of dead test objects was $16.7 \%$.

Table 3

Results of biotesting for acute toxic effects of water

\begin{tabular}{|c|c|c|}
\hline $\begin{array}{c}\text { Name of the sampling point } \\
\text { and repeatability }\end{array}$ & $\begin{array}{l}\text { Number of } \\
\text { daphnias }\end{array}$ & $\begin{array}{l}\text { Number of survivors } \\
\text { Daphne after } 96 \text { hours }\end{array}$ \\
\hline Control 1 & 10 & 10 \\
\hline Control 2 & 10 & 10 \\
\hline Control 3 & 10 & 10 \\
\hline $\begin{array}{l}\text { The average percentage of dead } \\
\text { daphnias }\end{array}$ & & $0 \%$ \\
\hline \multicolumn{3}{|c|}{ "Ternivska" mine } \\
\hline $\begin{array}{l}1.1 .500 \mathrm{~m} \text { above the discharge of } \\
\text { return water (rain and meltwater) }\end{array}$ & 10 & 7 \\
\hline 1.2. & 10 & 8 \\
\hline 1.3 . & 10 & 19 \\
\hline $\begin{array}{l}\text { The average percentage of dead } \\
\text { daphnias }\end{array}$ & \multicolumn{2}{|r|}{$20 \%$} \\
\hline $\begin{array}{l}\text { 2.1. Place of discharge of wastewater } \\
\text { (rain and meltwater) }\end{array}$ & 10 & 7 \\
\hline 2.2. & 10 & 8 \\
\hline 2.3 . & 10 & 10 \\
\hline $\begin{array}{l}\text { The average percentage of dead } \\
\text { daphnias }\end{array}$ & \multicolumn{2}{|r|}{$16,7 \%$} \\
\hline $\begin{array}{l}3.1 .500 \mathrm{~m} \text { below the discharge of } \\
\text { return water (rain and meltwater) }\end{array}$ & 10 & 7 \\
\hline 3.2. & 10 & 8 \\
\hline 3.3 . & 10 & 9 \\
\hline $\begin{array}{l}\text { The average percentage of dead } \\
\text { daphnias }\end{array}$ & \multicolumn{2}{|r|}{$20 \%$} \\
\hline
\end{tabular}


Comparing the data obtained with previous studies, there is a slight increase in the toxic effect of water on test objects from research sampling points near the "Ternivska" mine, but the indicators are within the within normal limits.

Phytoplankton. The phytoplankton of the Saksagan River in the studied areas of the "Ternivska" mine is mainly typical for small and medium-sized rivers of the Steppe zone of Ukraine. The phytoplankton of the river is depleted and consists of 7 systematic groups of algae, represented by 85 species (Fig. 1).

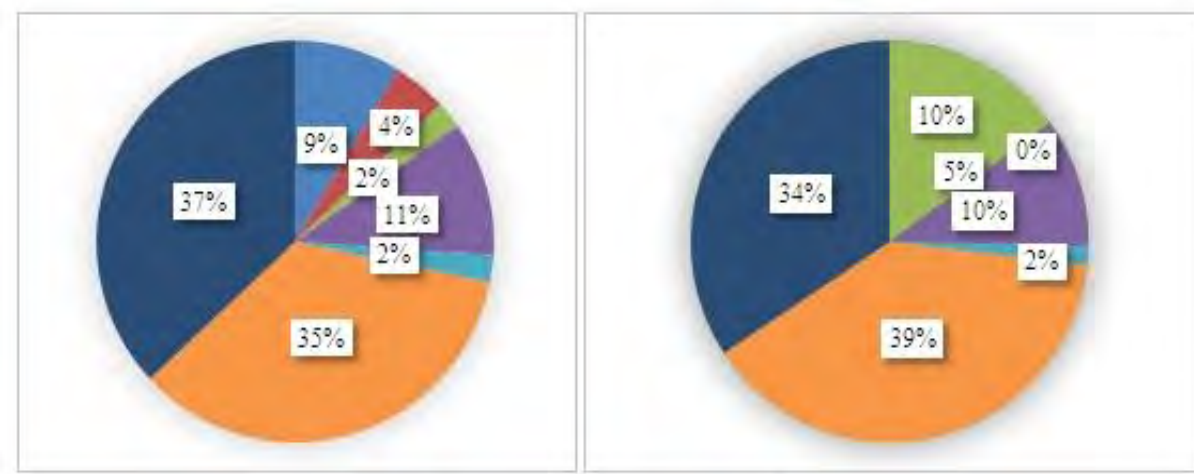

A

Б

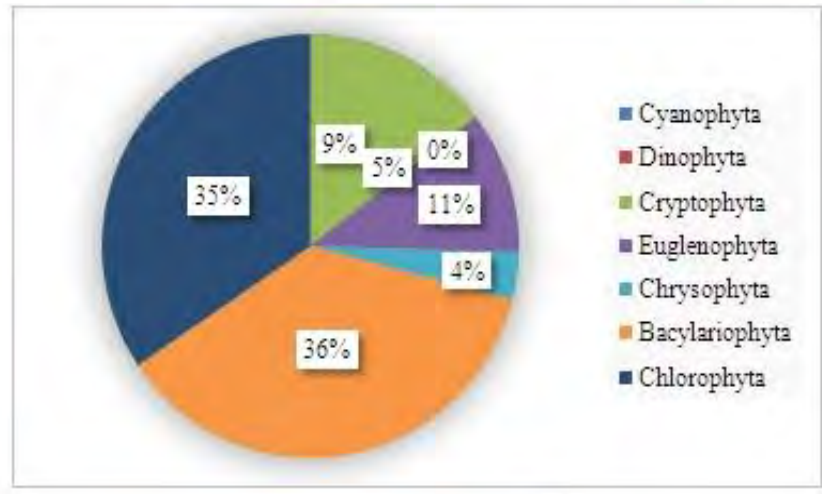

B

Figure 1. Percentage of algal taxonomic groups $A$-point № 1: $500 \mathrm{~m}$ above the discharge of return water (rain and meltwater); $B$ - point № 2: the place of return water discharge (rain and meltwater); $\mathrm{C}$ - point № 3: $500 \mathrm{~m}$ below the discharge of return water (rain and meltwater)

The phytoplankton is dominated by representatives of green algae (genera Clorella, Volvox, Ulotrix), which is typical for such reservoirs in the summer. Among diatoms, representatives of such genera as Melosira, Stephanodiscus, Nitzchia, Navicula, Asterionella, Gyrosigma, and Cyclotella predominates. Among the blue-green algae (genera Oscillatoria and Microcystis) there are indicators of beta-mesosaprobe (moderately polluted) zone. The total population and biomass are low. 
The highest number of algae was noted at the point $500 \mathrm{~m}$ above the wastewater discharge of the "Ternivska" mine (point 3) and reached 7.28 million cells $/ \mathrm{dm}^{3}$ with biomass of $8.26 \mathrm{mg} / \mathrm{dm}^{3}$. The smallest number of algae was in the place of discharge of wastewater (rain and meltwater) of the "Ternivska" mine and reached 5.92 million cells $/ \mathrm{dm}^{3}$ with biomass of $6.93 \mathrm{mg} / \mathrm{dm}^{3}$ (table 4).

Table 4

The number and biomass of phytoplankton groups in littoral areas of the Saksagan River near the "Ternivska" mine, June 2020

\begin{tabular}{|l|c|c|c|c|}
\hline \multirow{2}{*}{ Taxons } & \multirow{2}{*}{ Indicator } & \multicolumn{3}{|c|}{ "Ternivska" mine } \\
\cline { 3 - 5 } & & Point № 1 & Point № 2 & Point № 3 \\
\hline Bacillariophyta & $\mathrm{N}$ & 1.7 & 1.9 & 2.6 \\
\hline & $\mathrm{B}$ & 1.66 & 1.89 & 2.32 \\
\hline Cyanophyta & $\mathrm{N}$ & 0.9 & 1.5 & 1.6 \\
\hline & $\mathrm{B}$ & 0.51 & 0.09 & 0.13 \\
\hline Chlorophyta & $\mathrm{N}$ & 3.88 & 1.78 & 2.08 \\
\hline & $\mathrm{B}$ & 1.98 & 0.88 & 1.48 \\
\hline Euglenophyta & $\mathrm{N}$ & 0.21 & 0.16 & 0.12 \\
\hline & $\mathrm{B}$ & 1.07 & 0.99 & 0.66 \\
\hline Chryptophyta & $\mathrm{N}$ & 0.07 & 0.06 & 0.03 \\
\hline & $\mathrm{B}$ & 0.03 & 0.02 & 0.01 \\
\hline Dinophyta & $\mathrm{N}$ & 0.34 & 0.35 & 0.28 \\
\hline & $\mathrm{B}$ & 2.89 & 2.95 & 2.89 \\
\hline Chrysophyta & $\mathrm{N}$ & 0.18 & 0.17 & 0.22 \\
\hline & $\mathrm{B}$ & 0.12 & 0.11 & 0.12 \\
\hline Total: & $\mathbf{N}$ & $\mathbf{7 . 2 8}$ & $\mathbf{5 . 9 2}$ & $\mathbf{6 . 9 3}$ \\
\hline & $\mathrm{B}$ & $\mathbf{8 . 2 6}$ & $\mathbf{6 . 9 3}$ & $\mathbf{7 . 6 1}$ \\
\hline
\end{tabular}

Note: point № 1: $500 \mathrm{~m}$ above the discharge of return water (rain and meltwater); point № 2: the place of return water discharge (rain and meltwater); point № 3:500 m below the discharge of return water (rain and meltwater). $\mathrm{N}$ - number of phytoplankton, million cells $/ \mathrm{dm}^{3} ; \mathrm{B}$ - phytoplankton biomass, $\mathrm{mg} / \mathrm{dm}^{3}$

The algal flora complex found in the studied section of the Saksagan River near the "Ternivska" mine is not typical for clean rivers with their natural insignificant pollution and is typical for reservoirs influenced by anthropogenic load and overgrown with macrophytes.

In general, indicators of qualitative and quantitative development of phytoplankton in the Saksagan River in the studied areas indicate the accumulation of polluting deposits in the riverbed, the presence of industrial pollution in its waters, in addition to organic pollution. 
Microphytobenthos. The dominant representatives of microphytobenthos were diatoms (Bacillariophyceae), subdominant ones were blue-green algae (Cyanophyceae). Following diatoms had high development inexes: Navicula cryptocephala Kutz., a representative of phytoplankton and phytobenthos in shallow water areas of rivers in Ukraine; Staurosira construens Ehrenb., an eurytopic algae, a typical inhabitant of benthic fauna, common in shallow water on lightly silted sand; Cymbella tumidula Grun., common freshwater algae; Cyclotella sp., the representative of the phytobenthos and phytoperiphyton. Other representatives of diatoms that were found at sampling stations: Amphora veneta Kotz., facultative benthic algae that grow freely in the benthic littoral parts of the river, sometimes attached to large grains of sand; Asterionella formosa, a common representative of the periphyton and bottom sections of the littoral.

Blue-green algae are represented in a smaller amount, since there has not yet been an increase in water temperature for their mass development. Among the blue-green algae, the dominant microphytobenthos complex included 4 species: Aphanizomenon flos-aquae (L.) Ralfs, Merismopedia elegans, Oscillatoria ucrainica Vladimir. and Oscillatoria amphibian Ag. Aphanizomenon flos-aquae (L.) Ralfs and Merismopedia elegans are species that settle from the water column. The obligate benthic alga Oscillatoria ucrainica Vladim., was widely represented. It was found mainly on silted and slightly silted sand. Another facultative benthic and planktonic alga Oscillatoria amphibian Ag was found in significant quantities both on the bottom and in the water column of the littoral zone at all 3 research points near the "Ternivska" mine.

Zooplankton. 47 species were recorded in the zooplankton, including 28 rotifers, 11 copepods, 7 cladocerans, and 1 species of dreissens veligers (table 5).

Table 5

The number of zooplankton groups in the Saksagan River, June 2020

\begin{tabular}{|c|l|c|c|c|}
\hline \multirow{2}{*}{ № } & \multirow{2}{*}{ Taxons } & \multicolumn{3}{|c|}{ “Ternivska” mine } \\
\cline { 3 - 5 } & & Point № 1 & Point № 2 & Point № 3 \\
\hline 1 & Rotatoria & 16 & 19 & 18 \\
\hline 2 & Cladocera & 5 & 6 & 5 \\
\hline 3 & Copepoda & 9 & 6 & 6 \\
\hline 4 & Veliger Dreissena & 1 & 1 & 1 \\
\hline & Total & $\mathbf{3 1}$ & $\mathbf{3 2}$ & $\mathbf{3 0}$ \\
\hline
\end{tabular}

Note: point № 1: $500 \mathrm{~m}$ above the discharge of return water (rain and meltwater); point № 2: the place of return water discharge (rain and meltwater); point № 3: $500 \mathrm{~m}$ below the discharge of return water (rain and meltwater) 
The largest number of species was found at the point of discharge of return water (rain and meltwater) of the "Ternivska" mine and reached 32 species. The smallest number was noted below the discharge of return water (rain and meltwater) and reached 30 species, due to the absence of representatives of Rotatoria and Cladocera.

In the zooplankton composition during the studied period, the following species were dominant: Brachionus angularis, Euchlanis dilatata, Keratella quadrata, Bossmina longorostris, Moina macrocopa, Cyclops strenuous, Bipalpus hudsoni, Epiphanes senta, Lepadella sp., Synchaeta sp. These species were found at almost all research points (Appendix B). All these species were quite small. The detritivorous species were mostly presented by representatives of the Cladocera. Among the littoral biotopes, the largest number of species was observed in the open littoral, the smallest one in the macrophyte thickets.

The smallest number and biomass of zooplankton species was in the place of return water discharge (rain and meltwater) and amounted to 7.01 thous. ind. $/ \mathrm{m}^{3}$ with biomass of $0.07 \mathrm{~g} / \mathrm{m}^{3}$, respectively, which is more than in the autumn of 2019 (5.88 thous. ind. $/ \mathrm{m}^{3}$ with biomass of $0.04 \mathrm{~g} / \mathrm{m}^{3}$ ) (table 6 ).

Table 6

Number and biomass of zooplankton groups in littoral areas of the Saksagan River, June 2020

\begin{tabular}{|c|l|c|c|c|c|}
\hline \multirow{2}{*}{ № } & \multirow{2}{*}{ Taxons } & Indicator & \multicolumn{3}{|c|}{ “Ternivska” mine } \\
\cline { 4 - 6 } & & & Point № 1 & Point № 2 & Point № 3 \\
\hline 1 & Rotatoria & N & 5.02 & 1,85 & 19,44 \\
\hline & & $\mathrm{B}$ & 0.03 & 0.02 & 0.1 \\
\hline 2 & Cladocera & $\mathrm{N}$ & 0,04 & 0.03 & 0.05 \\
\hline & & $\mathrm{B}$ & 0.01 & 0.01 & 0.01 \\
\hline 3 & Copepoda & $\mathrm{N}$ & 22,15 & 5,12 & 19,32 \\
\hline & & $\mathrm{B}$ & 0,19 & 0.03 & 0.18 \\
\hline 4 & Veliger Dreissena & $\mathrm{N}$ & 0.01 & 0.01 & 0.01 \\
\hline & & $\mathrm{B}$ & 0.01 & 0.01 & 0.01 \\
\hline & \multirow{2}{*}{ Total } & N & $\mathbf{2 7 , 2 2}$ & $\mathbf{7 , 0 1}$ & $\mathbf{3 8 , 8 2}$ \\
\cline { 4 - 6 } & & B & $\mathbf{0 , 2 4}$ & $\mathbf{0 . 0 7}$ & $\mathbf{0 , 3}$ \\
\hline
\end{tabular}

Note: point № 1: $500 \mathrm{~m}$ above the discharge of return water (rain and meltwater); point № 2: the place of return water discharge (rain and meltwater); point № 3: $500 \mathrm{~m}$ below the discharge of return water (rain and meltwater). $\mathrm{N}$ - number of zooplankton, thous. ind. $/ \mathrm{m}^{3}$; B - zooplankton biomass, $\mathrm{g} / \mathrm{m}^{3}$ 
Despite the decrease in the number and biomass of zooplankton at the point of the direct impact on the aquatic ecosystem of the Saksagan River, at a distance of $500 \mathrm{~m}$ below the discharge of return water (rain and meltwater), there is a restoration of zooplankton biological diversity and an increase in its number and biomass to 38.82 thous. ind. $/ \mathrm{m}^{3}$ and $0.3 \mathrm{~g} / \mathrm{m}^{3}$, respectively.

Characteristics of zoobenthos. The benthic fauna of the studied areas of the Saksagan River near the "Ternivska" mine is characterized by a poor diversity. It contains 65 invertebrate species belonging to 21 taxonomic groups (table 7). The number of species for different sites ranged from 40 species (at the point $500 \mathrm{~m}$ above the discharge of return water (rain and meltwater) of the "Ternivska" mine) to 53 species (at the point of the discharge of return water (rain and meltwater) of the mine). The relative impoverishment of species diversity was noted as a result of silting and overgrowth of reeds in some parts of the river. There is a noticeable tendency to decrease the number of zoobenthos due to the loss of oxyphilous species, which indicates the deterioration of the river ecosystem.

The most common species were: Dreissena bugensis (Andrusov), Dreissena polymorpha, Unio pictorum, Physa fontinalis, Viviparus viviparous, Gastrosaccus Spinife, Nematoda sp., Limnodrilus hoffmeisteri, Tubifex tubifex, Limnomysis behedeni, Ecnomus tennelus, Chironomus sp., Cricotopus silvestris, Polypedilum convictum, Polypedium nubeculosum.

Table 7

Taxonomic composition of the zoobenthos representatives in the research sites of the Saksagan River, June 2020

\begin{tabular}{|c|c|c|c|c|}
\hline \multirow{2}{*}{ № } & \multirow{2}{*}{ Invertebrate taxa } & \multicolumn{3}{|c|}{ "Ternivska" mine } \\
\hline & & Point № 1 & Point № 2 & Point № 3 \\
\hline 1 & 2 & 3 & 4 & 5 \\
\hline 1 & Hydrozoa & 1 & 1 & 1 \\
\hline 2 & Bryozoa & 0 & 1 & 0 \\
\hline 3 & Bivalvia & 2 & 1 & 2 \\
\hline 4 & Gastropoda & 5 & 4 & 4 \\
\hline 5 & Nematoda & 1 & 1 & 1 \\
\hline 6 & Oligochaeta & 10 & 9 & 6 \\
\hline 7 & Hirudinea & 1 & 1 & 1 \\
\hline 8 & Gammaridae & 1 & 2 & 2 \\
\hline 9 & Misidacea & 1 & 2 & 1 \\
\hline 10 & Cumacea & 0 & 0 & 0 \\
\hline 11 & Decapoda & 0 & 1 & 0 \\
\hline 12 & Ephemiroptera & 2 & 2 & 2 \\
\hline 13 & Trichoptera & 1 & 2 & 1 \\
\hline 14 & Odonata & 1 & 1 & 1 \\
\hline
\end{tabular}


Table 7 (Continued)

\begin{tabular}{|c|l|c|c|c|}
\hline 1 & \multicolumn{1}{|c|}{2} & 3 & 4 & 5 \\
\hline 15 & Lepidoptera & 1 & 1 & 1 \\
\hline 16 & Heteroptera & 1 & 0 & 1 \\
\hline 17 & Coleoptera & 1 & 1 & 0 \\
\hline 18 & Chironomidae & 10 & 21 & 14 \\
\hline 19 & Ceratopogonidae & 0 & 0 & 0 \\
\hline 20 & Culicida & 0 & 0 & 0 \\
\hline 21 & Ephydridae & 0 & 0 & 1 \\
\hline 22 & Simmulidae & 1 & 0 & 1 \\
\hline 23 & Psychodidae & 0 & 1 & 1 \\
\hline 24 & Sciomyzidae & $\mathbf{4 0}$ & $\mathbf{5 3}$ & $\mathbf{4 1}$ \\
\hline & Total: &
\end{tabular}

Note: point № 1: $500 \mathrm{~m}$ above the discharge of return water (rain and meltwater); point № 2: the place of return water discharge (rain and meltwater); point № 3: $500 \mathrm{~m}$ below the discharge of return water (rain and meltwater)

In the area of operation of the "Ternivska" mine, the largest number and biomass of benthos was below the place of discharge of return water (rain and meltwater) (table 8). The smallest amount was in the place where rain and meltwater are discharged, which may be caused by the flow of the site.

Table 8

Number and biomass of the zoobenthos development

\begin{tabular}{|l|c|}
\hline \multicolumn{1}{|c|}{ Sampling stations } & June 2020 \\
\hline \multicolumn{1}{|c|}{ "Ternivska" mine } \\
\hline $\begin{array}{l}\text { 1.500 m above the discharge of return water (rain and } \\
\text { meltwater) }\end{array}$ & $\underline{3.46}$ \\
\hline 2. Place of discharge of wastewater (rain and meltwater) & $\frac{1.12}{2.56}$ \\
\hline $\begin{array}{l}\text { 3.500 m below the discharge of return water (rain and } \\
\text { meltwater) }\end{array}$ & $\underline{10.32}$ \\
\hline Average & $\underline{31.34}$ \\
\hline
\end{tabular}

Note: numerator - number, thous.ind. $/ \mathrm{m}^{2}$, denominator -biomass, $\mathrm{g} / \mathrm{m}^{2}$

Table 9 shows that the highest values of saprobity are recorded in areas with muddy soil: points 2,3 .

The oligochaetes dominate here, and saprobity increases in the direction of points: $500 \mathrm{~m}$ above the discharge of return water (rain and meltwater) - the place of the discharge (rain and meltwater) - $500 \mathrm{~m}$ below the discharge of return water (rain and meltwater), as the degree of siltation increases. 
The saprobity index of experimental sites

on the Saksagan River, June 2020

\begin{tabular}{|c|l|c|}
\hline $\begin{array}{c}\text { Station } \\
\text { number }\end{array}$ & \multicolumn{1}{|c|}{ Point characteristics } & $\begin{array}{c}\text { The saprobity } \\
\text { index }\end{array}$ \\
\hline \multicolumn{2}{|c|}{ "Ternivska" mine } \\
\hline 1 & $\begin{array}{l}500 \text { m above the discharge of return water } \\
\text { (rain and meltwater), rocky, silty clay }\end{array}$ & 2.34 \\
\hline 2 & $\begin{array}{l}\text { Place of discharge of wastewater } \\
\text { (rain and meltwater), muddy bottom }\end{array}$ & 3.32 \\
\hline 3 & $\begin{array}{l}500 \mathrm{~m} \text { below the discharge of return water } \\
\text { (rain and meltwater), muddy bottom, low flow }\end{array}$ & 3.98 \\
\hline
\end{tabular}

In the river, the highest saprobity indices are recorded in the area influenced by mines and below, which is associated with the development of oligochaetes from the Tubificidae family, and polysaprobic species of the Chironomus genus. On such soils, there is the greatest species diversity among other soils, owing to chironomid larvae. Isopods, dayflies, leeches, predatory chironomids, a great number of oligochaetes are inherent in silts and significantly silted sands below and above the mines.

The average number of invertebrates within the area influenced by "Ternivska" mine operation was 4.96 thous. ind. $/ \mathrm{m}^{2}$ with biomass of $12.34 \mathrm{~g} / \mathrm{m}^{2}$, which is higher than in the autumn of 2019 .

No rare or endangered species have been found among the benthic groups.

Ichthyofauna. The ichthyofauna of Kryvyi Rih district has 37 species of 75 species inhabiting the territory of the Dnipropetrovsk region. Ten species of fish among them are listed in the "Red book of the Dnepropetrovsk region": burbot (Lota lota L.), gudgeon (Gobio gobio L.), vimba bream (Vimba vimba L.), common dace (Leuciscus leuciscus L.), ide (Leuciscus idus L.), crucian carp (Carassius carassius L.), weatherfish (Misgurnus fossilis L.), stone loach (Barbatula barbatula L.), three-spined stickleback (Gasterosteus aculeatus L.), common percarina (Percarina demidoffii Nordmann). The regulation of the flow of the Ingulets and Saksagan rivers has affected the formation of ichthyofauna and led to the reformation of fauna complexes and trophic groups of fish. Such changes have affected the species composition and number of fish groups. Due to artificial stocking with fish, the ichthyofauna of the reservoir is enriched with introduced species: grass carp (Ctenopharyngodon idella Valenciennes), Prussian carp (Carassius gibellio Bloch), and silver carp (Hypophthalmichthys molitrix Valenciennes), which are mainly released for biomelioration.

In recent years, the ichthyofauna of the region has been enriched due to the invasion of alien species. For example, following species have entered the 
Saksagan River through the Dnieper-Kryvyi Rih channel and the Ingulets River: kilka (Clupeolla delicatula Nordmann), black-striped pipe fish (Syngnathus nigrolineatus Eichwald), three-spined stickleback (Gasterosteus aculeatus L), round goby (Neogobius melanostomus Pallas), pumpkinseed (Lepomis gibbosus L.).

The following species of fish are of industrial and fishery importance: roach (Rutilus rutilus L.), white bream (Blicca bjoerkna L.), bream (Abramis brama L.), carp (Cyprinus carpio L.), perch (Perca fluviatilis L.), zander (Lucioperca lucioperca L.), northern pike (Esox lucius L.), which are found in different parts of the river.

Within the studied stations, the modern fish species composition consists of 15 species of fish that belonged to 6 families (Clupeidae - 1; Cyprinidae - 7; Siluridae -1, Cobitidae - 1; Centrarchidae - 1; Gobiidae - 4) (table 11), which is $40.5 \%$ of the total fish species composition of the Saksagan River for the entire period of ichthyological research (since the 30 s of the XX century). In the previous research period, in the second half of 2019, 14 species of fish were recorded on the river section, which is one species less. The species composition of the river was replenished with species of the gudgeon family: racer goby, round goby, tubenose goby, as well as with functionally dangerous self-colonized group of alien species such as stone moroko and pumpkinseed.

The studied section of the river is now dominated by a short-cycle fish species such as stone moroko, bitterling, and bleack. As in the previous year, the ichthyocenosis is dominated by short-cycle species with a high range of adaptations to transformed reservoirs (exception for the widespread common rudd). In the previous research period $(2012,2018,2019)$, the dominance of these species was also observed. The number of bleack reached 73.25 ind. $/ 100 \mathrm{~m}^{2}$ at a point $500 \mathrm{~m}$ below the discharge of return water (rain and meltwaters) of the "Ternivska" mine, with an average number and biomass in the area influenced by the mine accounting to 54.26 ind. $/ 100 \mathrm{~m}^{2}$ and $155.92 \mathrm{~g} / 100 \mathrm{~m}^{2}$, respectively (table 10). In the long-term aspect, the number of bleak remained at a consistently high level of 185 ind./100 $\mathrm{m}^{2}$ in $2012,65.82$ ind. $/ 100 \mathrm{~m}^{2}$ in 2019 , respectively. The number of bitterling fluctuates significantly, which is caused by cyclical phenomena of its reproduction: in 2006, its number was ind. $/ 100 \mathrm{~m}^{2}$, in $2018-392$ ind./100 $\mathrm{m}^{2}$, in the second half of $2019-49.39$ ind./100 $\mathrm{m}^{2}$. In June 2020 , sexually mature individuals of the bitterling, which laid eggs on the river sections were observed.

The structure of the ichthyofauna is enriched by the appearance of threesummer-old $(2+)$ roach, the number of three-summer-old Prussian carp has increased, and the number of pumpkinseed that built spawning nests near the shore has increased. 


\section{Species composition, number and biomass of fish in the Saksagan River, June 2020}

\begin{tabular}{|c|c|c|c|c|c|c|c|c|c|c|}
\hline \multirow[b]{3}{*}{ No } & \multirow[b]{3}{*}{ Species of fish } & \multirow[b]{3}{*}{ age } & \multicolumn{8}{|c|}{ "Ternivska" mine } \\
\hline & & & \multicolumn{2}{|c|}{ Point № 1} & \multicolumn{2}{|c|}{ Point № 2} & \multicolumn{2}{|c|}{ Point № 3} & \multicolumn{2}{|c|}{ Average } \\
\hline & & & 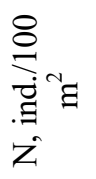 & 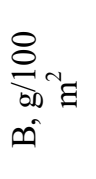 & 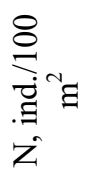 & $\stackrel{8}{\infty}_{\substack{\infty \\
\infty}}$ & 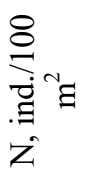 & 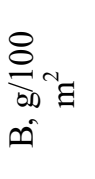 & 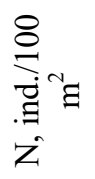 & $\stackrel{8}{\infty}_{\substack{\infty \\
\infty}}$ \\
\hline 1 & 2 & 3 & 4 & 5 & 6 & 7 & 8 & 9 & 10 & 11 \\
\hline \multicolumn{11}{|c|}{ Clupeidae family Clupeidae Cuvier, 1816} \\
\hline 1 & \begin{tabular}{|l|} 
Azov Sea kilka \\
Clupeonella cultriventris \\
(Nordmann, 1840) \\
\end{tabular} & $\mathrm{n} / \mathrm{a}$ & 1.88 & 1.02 & - & - & - & - & 0,63 & 0.34 \\
\hline \multicolumn{11}{|c|}{ Cyprinidae family Cyprinidae Fleming, 1822} \\
\hline 2 & $\begin{array}{l}\text { Bleack Alburnus alburnus } \\
\text { (Linnaeus, 1758) }\end{array}$ & $\mathrm{n} / \mathrm{a}$ & 25.12 & 93,22 & 64,42 & 198,14 & 73,25 & 176,4 & 54,26 & 155,92 \\
\hline \multirow[t]{3}{*}{3} & \multirow{3}{*}{$\begin{array}{l}\text { Prussian carp Carassius } \\
\text { gibelio (Bloch, 1782) }\end{array}$} & $0+$ & 4,31 & 0,14 & 3.12 & 2,18 & 2,24 & 2,63 & 3,22 & 1,65 \\
\hline & & $1+$ & 0,58 & 1.12 & 1,16 & 2,25 & 1,06 & 1,34 & 0,93 & 1,57 \\
\hline & & $2+$ & 0,55 & 16,3 & 0,65 & 14,5 & - & - & 0,40 & 10,27 \\
\hline 4 & $\begin{array}{l}\text { Sunbleak Leucaspius } \\
\text { delineatus (Heckel, 1843) }\end{array}$ & $\mathrm{n} / \mathrm{a}$ & 0.88 & 0,08 & - & - & 0,32 & 0.06 & 0,40 & 0.05 \\
\hline 5 & $\begin{array}{l}\text { Stone morokko } \\
\text { Pseudorasbora parva } \\
\text { (Temminck et Schlegel, } \\
1846 \text { ) }\end{array}$ & $\mathrm{n} / \mathrm{a}$ & 27.25 & 2,46 & 15,19 & 2,46 & 14,12 & 2,06 & 18,85 & 2,33 \\
\hline 6 & $\begin{array}{l}\text { Bitterling Rhodeus amarus } \\
\text { (Bloch, 1782) }\end{array}$ & $\mathrm{n} / \mathrm{a}$ & 58,44 & 6,89 & 32,19 & 3.98 & 41,16 & 4,95 & 43,93 & 5,27 \\
\hline \multirow[t]{3}{*}{7} & \multirow{3}{*}{$\begin{array}{l}\text { Roach Rutilus rutilus } \\
\text { (Linnaeus, 1758) }\end{array}$} & $0+$ & 2,44 & 0,78 & 0,75 & 0.22 & 1,42 & 0,56 & 1,54 & 0,52 \\
\hline & & $1+$ & 0.12 & 0,42 & 0.21 & 2,52 & 0,43 & 2,74 & 0,25 & 1.89 \\
\hline & & $2+$ & 0.16 & 5,34 & - & - & - & - & 0.05 & 1.78 \\
\hline \multirow[t]{3}{*}{8} & \multirow{3}{*}{$\begin{array}{l}\text { Common rudd Scardinius } \\
\text { erythrophthalmus } \\
\text { (Linnaeus, 1758) }\end{array}$} & $0+$ & 4,34 & 0,49 & 4,43 & 0,55 & 7,01 & 0,84 & 5,26 & 0,63 \\
\hline & & $1+$ & 14,23 & 1,44 & 10,15 & 1,32 & 17,28 & 2,43 & 13,89 & 1,73 \\
\hline & & $2+$ & 0.02 & 2,64 & 0,32 & 12,23 & - & - & 0.11 & 4.96 \\
\hline \multicolumn{11}{|c|}{ Cobitidae family Cobitidae Swainson, 1839} \\
\hline 9 & $\begin{array}{l}\text { Weatherfish Cobitis taenia } \\
\text { Linnaeus, } 1758 \\
\end{array}$ & $\mathrm{n} / \mathrm{a}$ & 0.64 & 0,19 & 0,72 & 0.18 & 0,78 & 0,24 & 0,54 & 0,20 \\
\hline \multicolumn{11}{|c|}{ Centrarchidae family Centrarchidae Bleeker, 1759} \\
\hline 10 & $\begin{array}{l}\text { Pumpkinseed Lepomis } \\
\text { gibbosus (Linnaeus, 1758) }\end{array}$ & $\mathrm{n} / \mathrm{a}$ & - & - & 18,21 & 167,23 & - & - & 6,07 & 55,74 \\
\hline \multicolumn{11}{|c|}{ Gobiidae family Gobiidae Fleming, 1822} \\
\hline 11 & $\begin{array}{l}\text { Racer goby Babka } \\
\text { gymnotrachelus (Kessler, } \\
1857 \text { ) }\end{array}$ & $\mathrm{n} / \mathrm{a}$ & 1.02 & 0.11 & 3,18 & 0,46 & - & - & 1,40 & 0,19 \\
\hline 12 & $\begin{array}{l}\text { Monkey goby Neogobius } \\
\text { fluviatilis (Pallas, 1814) }\end{array}$ & $\mathrm{n} / \mathrm{a}$ & - & - & 0,43 & 0.05 & 0,53 & 0.06 & 0,32 & 0,04 \\
\hline 13 & $\begin{array}{l}\text { Round goby Neogobius } \\
\text { melanostomus } \\
\text { (Pallas, 1814) }\end{array}$ & $\mathrm{n} / \mathrm{a}$ & 4,12 & 0,68 & - & - & 4,45 & 0,69 & 2,86 & 0,46 \\
\hline 14 & $\begin{array}{l}\text { Tubenose goby } \\
\text { Proterorhinus marmoratus } \\
\text { (Pallas, 1814) }\end{array}$ & $\mathrm{n} / \mathrm{a}$ & - & - & 3,36 & 0,71 & 3,54 & 0,46 & 2,30 & 0,39 \\
\hline
\end{tabular}


Table 10 (Continued)

\begin{tabular}{|c|c|c|c|c|c|c|c|c|c|c|}
\hline 1 & 2 & 3 & 4 & 5 & 6 & 7 & 8 & 9 & 10 & 11 \\
\hline \multicolumn{11}{|c|}{ Siluridae family Siluridae Cuvier, 1816} \\
\hline 15 & $\begin{array}{l}\text { Wels catfish Silurus glanis } \\
\text { (Linnaeus, 1758) }\end{array}$ & $\mathrm{n} / \mathrm{a}$ & 0.02 & 22,31 & - & - & - & - & 0.01 & 5,58 \\
\hline & Total: & & 146,1 & 133,32 & 158,49 & 408,98 & 167,59 & 195,46 & 157,22 & 245,92 \\
\hline
\end{tabular}

Note: point № 1: $500 \mathrm{~m}$ above the discharge of return water (rain and meltwater); point № 2: the place of return water discharge (rain and meltwater); point № 3: $500 \mathrm{~m}$ below the discharge of return water (rain and meltwater). $\mathrm{N}$ - number of ind. $/ 100 \mathrm{~m}^{2} \mathrm{~B}-$ biomass $\mathrm{g} / 100 \mathrm{~m}^{2} ;$ Age $-\mathrm{n} / \mathrm{a}$-without age determination, $0+-$ yearling, $1+-$ two summers, $2+-$ three summers, $3+-$ four summers. "--" the species was not found in the catches

The wide variation in fish amounts is also related to the sampling season and water temperature. The trend of spread and numerical dominance of short-cycle species can be explained by the lack of places for effective natural spawning and feeding of juveniles of other fish species that are more demanding to the conditions of natural reproduction, as well as by the impact of municipal and industrial wastewater, and other negative factors. In June 2020, the section of the Saksagan River, which is influenced by the "Ternivska" mine operation, was characterized by the following indicators of fish number and biomass: 157.22 ind./100 $\mathrm{m}^{2}$ and $245.92 \mathrm{~g} / 100 \mathrm{~m}^{2}$, respectively.

During the research period, fish that have a protected status and are listed In the Red book of the Dnipropetrovsk region and the Red book of Ukraine were not detected within the area of the planned poeration of the "Ternivska" mine.

\section{CONCLUSIONS}

Thus, the results of complex hydrobiological studies have revealed the following findings:

1. By the content of ammonium nitrogen $\left(\mathrm{NH}_{4}{ }^{+}\right)$at all research points, the river water belongs to the 1 st class of quality. The content of nitrites at all research points does not exceed the maximum permissible concentrations and corresponds to the 2nd class of water quality. The content of nitrates $\left(\mathrm{NO}_{3}{ }^{-}\right)$at all research sites also did not exceed the maximum permissible concentrations and corresponded to the 3rd class of water quality. The content of iron $\left(\mathrm{Fe}^{2+}\right)$ in the water at the experimental points was satisfactory and corresponded to the 1st quality class. The content of phosphates corresponded to the standards of DSTU 4808: 2007.

2. According to the results of biotesting on Daphnia, no acute toxic effects of water were detected at any experimental site near the "Ternivska" mine.

3. A direct negative effect on phytoplankton is not observed. Mainly the lowest number and algae biomass were observed at the points of discharge of return water (rain and meltwater) of the mine (points 2,3). Despite this, the recovery of phytoplankton occurs quite quickly; in the summer period, it takes a few days. 
4. During the study period, it has been established that the planned operation of the "Ternivska" mine does not harm the microphytobentos groups.

5. Zooplankton of the Saksagan River does not undergo significant changes under the influence of planned operation of the "Ternivska" mine (due to wastewater) because of its high adaptive and regenerative capacity and is in a fairly satisfactory environmental condition.

6. In 2020, as in 2019, there was an increase in the saprobity index in the direction from the point $500 \mathrm{~m}$ above the discharge of return water (rain and meltwater) to the point of discharge of return water (rain and meltwater) and $500 \mathrm{~m}$ below the discharge of return water (rain and meltwater) as the degree of siltation of the river increases. Taking into account the species diversity and structural indicators of zoobenthos, it has been found that zoobenthos groups do not undergo significant changes caused by the planned operation of the "Ternivska" mine.

7. The structure of the ichthyofauna near the "Ternivska" mine is simplified and of short-cycle fish species dominate there. This depletion of the species diversity of the ichthyofauna can be explained by the influence of anthropogenic impact on the river ecosystem.

8. During the research period, no rare or endangered species were found for the flora and fauna of Ukraine at the experimental site.

\section{SUMMARY}

Currently, there is a strong demand for environmental biomonitoring over the quality of the water environment being the habitat of hydrobionts, which is influenced by mining enterprises. The quality of the water environment often deteriorates because of the operation of mining enterprises, which affects the numerical and species composition of different groups of hydrobionts. The hydrobiocenosis of the Saksagan River is an example of such transformations. This river flows through the industrial agglomeration of Krivyi Rih and is subjected to a significant anthropogenic load.

The paper presents the results of complex monitoring hydrobiological studies over the Saksagan River as part of the planned operation of the "Ternivska" mine. Hydrochemical indicators of water quality have been determined. The biotesting with the use of Daphnia has shown that there is no acute toxicity of the aquatic environment. It has been found that the species composition of hydrobionts (phytoplankton, zooplankton, phytobenthos, microphytobenthos, and ichthyofauna) naturally has a simplified structure, which is typical for reservoirs under anthropogenic load. It has been noted that in terms of simplification of the ichthyofauna structure an observed increase in fish biodiversity is caused by the spread of invasive species, mainly pumpkinseed, stone moroko, and three-spined stickleback. 


\section{REFERENCES}

1. Методи гідроекологічних досліджень поверхневих вод / під ред. В.Д. Романенко. Київ, 2006. 628 с.

2. Методические рекомендации по сбору и обработке материалов при гидробиологических исследованиях. Зоопланктон и его продукция. Ленинград : ЗИН, 1984. 35 с.

3. Гринь В.Г. Об'ємно-вагова характеристика провідних видів фітопланктону Нижнього Дніпра. Питання екології і ценології водних організмів Дніпра. АН УССР. Київ, 1963. С. 35-40.

4. Щербак В.І. Методи досліджень фітопланктону. Методичні основи гідробіологічних досліджень водних екосистем. Київ, 2002. С. 41-48.

5. Жадин В.И. Методика изучения донной фауны водоемов и экология донных беспозвоночных). Жизнь пресных вод СССР. Москва : Наука, 1956. T. 4. Ч. 1. С. $279-382$.

6. Озінковська С.П., Єрко В.М., Коханова Г.Д., Тарасова О.М., Полторацька B.I. Методика збору і обробки іхтіологічних і гідробіологічних матеріалів 3 метою визначення лімітів промислового вилучення риб з великих водосховищ і лиманів України. Київ : IPГ УААН, 1998. $47 \mathrm{c.}$

7. Исследования размножения и развития рыб : методическое пособие / под ред. Б.В. Кошелева, М.В. Гулидова. Москва : Наука, 1981. 224 с.

8. Кузнецов В.А. Количественный учет молоди рыб в водохранилищах и озерах (методические подходы и возможности). Типовые методики исследования продуктивности видов рыб в пределах их ареалов. Вильнюс, 1985. С. 26-35.

9. Коблицкая А.Ф. Определитель молоди пресноводных рыб. Москва : Легк. и пищ. пром-сть, 1981. 208 с.

\section{Information about authors:} Marenkov O. M., Candidate of Biological Sciences, Head of the Department of General Biology and Water Bioresources Oles Honchar Dnipro National University 72, Gagarin ave., Dnipro, 49050, Ukraine

Nesterenko O.S.

MS (Biology),

$\mathrm{PhD}$ Student at the Department of General Biology and Water Bioresources Oles Honchar Dnipro National University 72, Gagarin ave., Dnipro, 49050, Ukraine 